\title{
УДОСКОНАЛЕННЯ ІНСТИТУТУ ДОКАЗУВАННЯ У СПРАВАХ ПРО ПОРУШЕННЯ МИТНИХ ПРАВИЛ
}

\author{
Білак Н. І., Чернявська О. М.
}

\section{ВСТУП}

Національна митна система в черговий раз потрапляє під процес реорганізаційних змін. Відповідно до Постанови Кабінету Міністрів від 18 грудня 2018 р. № 1200른 прийнято рішення про реорганізацію Державної фіскальної служби України шляхом її поділу на дві служби: Державну податкову службу України та Державну митну службу України. Новостворені служби отримали статус центрального органу виконавчої влади з питань забезпечення реалізації державної політики в податковій і митній сферах (відповідно).

За останніх декілька років це вже 3 реорганізаційна зміна. Відокремлення митної служби є обгрунтованим та економічно доцільним. Повернення до попередньої автономної форми управління дасть змогу покращити роботу, зміцнити контроль за всіма напрямами, зосередити увагу на проблемних питаннях саме митної служби та розробити дієві заходи їх вирішення.

Відповідно до Положення про Державну митну службу України, затвердженого Постановою Кабінету Міністрів від 6 березня 2019 р. № 227, до повноважень новоствореної Державної митної служби України серед іншого зараховано: 1) здійснення контролю за дотриманням вимог законодавства під час провадження у справах про порушення митних правил; 2) боротьба з порушеннями митних правил; 3) виявлення причин та умов, що сприяли вчиненню правопорушень у сфері державної митної справи, ужиття заходів до їх усунення тощо 2 .

Вищенаведені норми свідчать, що фактично до новоутвореної Державної митної служби України перейшли всі повноваження в частині здійснення провадження у справах про порушення митних правил, якими була наділена й Державна фіскальна служба. Однак чинні повноваження, як і закріплені в нормативно-правових актах

\footnotetext{
1 Про утворення Державної податкової служби України та Державної митної служби України : Постанова Кабінету Міністрів від 18 грудня 2018 р. № 1200 / Верховна Рада України. URL: https://www.kmu.gov.ua/npas/pro-utvorennya-derzhavnoyi-podatkovoyi-sluzhbiukrayini-ta-derzhavnoyi-mitnoyi-sluzhbi-ukrayini (дата звернення: 28.02.2020).

2 Положення про Державну митну службу України : Постанова Кабінету Міністрів України від 6 березня 2019 р. № 227 / Верховна Рада України. URL: https://zakon.rada.gov.ua/ laws/show/227-2019-\%D0\%BF/print\#n209 (дата звернення: 28.02.2020).
} 
положення, якими врегульовано здійснення провадження у справах про порушення митних правил, фактично не переглядалися вже тривалий час.

В умовах реформ, які відбуваються в Україні, відкривається унікальна можливість запровадити сучасні методи розгляду справ про порушення митних правил і сформувати ефективний механізм доказування, удосконаливши здійснення провадження митних справ, що, у свою чергу, сприятиме якісному виконанню завдань, покладених перед новоствореною Державною митною службою України.

Загальнотеоретичним питанням здійснення провадження у справах про порушення митних правил, дослідженню доказів і доказуванню приділяли увагу такі науковці, як В.Д. Андрійцьо, О.О. Бадила, С.С. Бичкова, Білоусов, Ю.П. Битяк, С.В. Васильєв, О.О. Грабовська, А.В. Дусик, М.О. Гетманцев, О.С. Захарова, А.С. Зеленяк, Я.П. Зейкан, А.Ю. Каламайко, Т.М. Кілічаєва, В.А. Кройтор, Б.А. Кормич, В.В. Комаров, Т.М. Кучер, С.В. Курильов, Н.А. Новікова, В.В. Нижникова, А.С. Павлова, В.В. Прокопенко, Б.П. Ратушна, О.В. Рожнов, Т.В. Руда, Т.С. Супрун, В.І. Тертишніков, Г.П. Тимченко, С.Я. Фурса, С.О. Харитонов, В.О. Ходанович, Т.В. Цюра, А.С. Штефан, М.М. Ясинок, К.А. Сергєєва, М.К. Треушніков, В.А. Черепанов та інші. Досить «вузькій» тематиці доказів і доказування у справах про порушення митних правил присвячували розробки такі автори, як С.А. Дуженко, Д.В. Приймаченко, І.В. Солопова, у ширшому аспекті теорія доказів в адміністративному процесі досліджувалася Д.М. Бахрахом, І.П. Голосніченком, С.В. Додіним, С.В. Ківаловим та іншими. Їхні праці заклали вагоме підгрунтя подальших наукових пошуків у царині доказування в митному праві, відкрили шляхи оновлення цього інституту й визначили основні вектори майбутніх розвідок та оновлення чинного законодавства ${ }^{3}$.

Незважаючи на наявність численних досліджень проблем у сфері доказового права, питанням процесу встановлення істини у справах про порушення митних правил приділено мало уваги. Більшість праць стосуються доказування в судовому процесі, здійсненню провадження у справах про порушення митних правил, класифікації та характеристиці доказів тощо. 3 урахуванням часу навіть наявні дослідження є необхідними.

\footnotetext{
3 Чернявська O.M. Докази та доказування у справах про порушення митних правил: до питання вдосконалення правового забезпечення. Lex portus. 2019. № 3. C. 51. URL: http://nbuv.gov.ua/UJRN/LP_2019_3_6.
} 
Метою наукового дослідження є проведення детального аналізу національної законодавчої бази, якою врегульовані відносини щодо здійснення доказування у справах про порушення митних правил, а також наукових напрацювань, з урахуванням цього розроблення комплексу дієвих заходів, спрямованих на покращення процесу встановлення істини під час здійснення провадження у справах про порушення митних правил, перегляду обсягу компетенції посадової особи митного органу, налагодження взаємодії з іншими національними органами та міжнародними інституціями.

\section{1. Характеристика структури процесу доказування у справах про порушення митних правил}

Процес доказування в національному митному законодавстві врегульовано лише поверхово, безпосередньо пов'язаний зі здійсненням провадження у справах про порушення митних правил. У Митному кодексі України зазначено, що провадження у справах про порушення митних правил здійснюється відповідно до цього Кодексу, а в частині, що не регулюється ним, - відповідно до законодавства України про адміністративні правопорушення 4 . Водночас Кодексом України про адміністративні правопорушення передбачено, що законодавство України про адміністративні правопорушення складається із цього Кодексу та інших законів України. Питання щодо адміністративної відповідальності за порушення митних правил регулюються Митним кодексом України

Однак ані Митний кодекс України, ані Кодекс України про адміністративні правопорушення не є процесуальними кодифікованими нормативно-правовими актами. У зв'язку з такою ситуацією багато питань, зокрема щодо правового статусу осіб, які беруть участь у розгляді судом справ про порушення митних правил (у тому числі митного органу), залишаються невизначеними, що призводить на практиці до порушення основних принципів правосуддя, неоднакової практики застосування судами законодавства, зловживань судом своїми повноваженнями й інших негативних наслідків ${ }^{6}$.

\footnotetext{
4 Митний кодекс України : Закон України від 13 березня 2012 р. № 4495-VI / Верховна Рада України. URL: https://zakon.rada.gov.ua/laws/show/4495-17 (дата звернення: 28.02.2020).

Кодекс України про адміністративні правопорушення : Закон України від 7 грудня 1984 р. № 8073-X / Верховна Рада України. URL: https://zakon.rada.gov.ua/laws/show/ 80731-10 (дата звернення: 28.02.2020).

6 Білак Н.І., Прокопенко В.В. Переміщення товарів, які містять об’єкти права інтелектуальної власності, через митний кордон України : монографія. Дніпро : Університет митної справи та фінансів, 2019. С. 148-149.
} 
Питанням доказування присвячено статтю 495 Митного кодексу України, яка має назву «Докази у справі про порушення митних правил». У цій статті Митного кодексу України надається визначення поняття «докази у справі про порушення митних правил» і перераховуються дані (документи, інформація, товари і транспортні засоби), на основі яких у визначеному законом порядку встановлюються наявність або відсутність порушення митних правил, винність особи в його вчиненні та інші обставини, що мають значення для правильного вирішення справи. Однак саме визначення «доказування у справах про порушення митних правил» у митному законодавстві відсутнє.

Для порівняння, у Кримінальному процесуальному кодексі України доказам і доказуванню присвячено главу 4, а доказуванню - окремий параграф. Відповідно до статті 91 Кримінального процесуального кодексу України, доказування полягає в збиранні, перевірці та оцінюванні доказів $з$ метою встановлення обставин, що мають значення для кримінального провадження ${ }^{7}$. Глава під назвою «Докази та доказування» наявна також у Цивільному процесуальному кодексі України Кодексі адміністративного судочинства України ${ }^{9}$. У вищезазначених процесуальних кодексах детально регулюється порядок і межі здійснення доказування з урахуванням особливостей, притаманних правовідносинам, які вони регламентують.

У цьому випадку буде доцільно зазначити думку І.В. Солопової, що провадження у справах про порушення митних правил і контрабанду є одним із видів процесуальної діяльності органів доходів і зборів. Процесуальним обов'язком є встановлення всіх обставин учиненого правопорушення у формі доказування, за якої ступінь категоричності суджень і висновків має бути дуже високим. Тому доведення посідає центральне місце в адміністративно-процесуальній діяльності органів доходів і зборів ${ }^{10}$.

\footnotetext{
7 Кримінальний процесуальний кодекс : Закон України від 13 квітня 2012 р. № 4651-VI / Верховна Рада України. URL: https://zakon.rada.gov.ua/laws/show/4651-17/card6\#Public (дата звернення: 28.02.2020).

8 Цивільний процесуальний кодекс України: Закон України від 18 березня 2004 р. № 1618-IV / Верховна Рада України. URL: https://zakon.rada.gov.ua/laws/show/1618-15/print (дата звернення: 28.02.2020).

9 Кодекс адміністративного судочинства України : Закон України від 6 липня 2005 р. № 2747-IV / Верховна Рада України. URL: https://zakon.rada.gov.ua/laws/show/2747-15/print (дата звернення: 28.02.2020).

10 Солопова І.В. Специфіка доказування у митних провадженнях. Актуальні проблеми політики. 2015. Вип. 56. С. 280.
} 
У справі про порушення митних правил процесуальні дії проводяться $з$ метою отримання доказів, необхідних для правильного вирішення цієї справи. В.В. Прокопенко надає авторське визначення поняття «процесуальні дії» як дій учасників процесу, що вчиняються ними $з$ метою реалізації процесуальних прав, на основі здійснення дослідження наукової літератури, адміністративного та митного законодавства визначаючи характерні ознаки процесуальних дій у справах про порушення митних правил ${ }^{11}$.

Здійснювані процесуальні дії в теоретичному аспекті деякі автори розподіляють на етапи: початковий, подальший і заключний. На початковому етапі потрібно провести пошук, виявлення й закріплення доказів з метою отримання інформації, яка дає підставу для висунення версії про вчинення правопорушення певною особою ${ }^{12}$.

Можна дійти висновку, що деяким елементам доказового процесу у справах про порушення митних правил також властиві ознаки процесуальних дій.

О.О. Грабовською в дисертаційному дослідженні сформульовано поняття «доказування в цивільному процесі» як пізнавально-практичної діяльності учасників справи, яка: 1) зумовлена юридичною заінтересованістю; 2) урегульована сукупністю законодавчих актів національного й наднаціонального характеру; 3) заснована на основоположних принципах цивільного процесуального права; 4) спрямована на переконання суду в тому, що факти та обставини, якими обгрунтовано вимоги чи заперечення, підтверджують заявлені вимоги; 5) реалізується за допомогою встановлених законом засобів; 6) здійснюється під процесуальним керівництвом суду та за його сприяння ${ }^{13}$.

Д.В. Приймаченко вказує, що доказування у провадженні в справах про порушення митних правил за змістом являє собою складну систему, у якій органічно переплітається розумова та практична діяльність суб'єктів доказування й ті відносини, які виникають у зв'язку із цією діяльністю між учасниками митних розслідувань. Розглядаючи доказування як систему, автор розрізняє іï структурні елементи,

11 Прокопенко В.В., Калакайло Р.І. Процесуальні дії у справах про порушення митних правил : монографія. Чернівці :Техгодрук, 2015. С. 31.

12 Чернявська O.M. Докази та доказування у справах про порушення митних правил: до питання вдосконалення правового забезпечення. Lex portus. 2019. № 3. C. 53. URL: http://nbuv.gov.ua/UJRN/LP_2019_3_6 (дата звернення: 28.02.2020).

13 Грабовська О.О. Теоретико-правові проблеми доказування у цивільному процесі України : автореф. дис. ... докт. юрид. наук. Київ, 2019. C. 7. URL: http://scc.univ.kiev.ua/ upload/iblock/e43/aref_Grabovska\%200.\%20A..pdf (дата звернення: 28.02.2020). 
a саме: збирання доказів, їх дослідження та оцінювання. На думку Д.В. Приймаченка, доказування у провадженні в справах про порушення митних правил - заснована на законі й регламентована нормами Митного кодексу України та адміністративно-процесуальними нормами діяльність уповноважених осіб органів митної служби, яка спрямована на своєчасне, повне й об'єктивне з'ясування обставин кожної справи, а також на виявлення причин та умов щодо вчинення порушення митних правил ${ }^{14}$.

Такі вчені, як С.Я. Фурса та Т.В. Цюра, уважають за необхідне розширити термінологічну базу процесу доказування шляхом розмежування понять «доказування» та «доведення» ${ }^{15}$. Під «доказуванням», продовжують учені, варто розуміти регламентовану в певний порядок процесуальну діяльність зі збирання, витребування (для адвокатів і прокурорів) і надання суду доказів суб' єктам, що за цивільним процесуальним законодавством вправі надавати докази в конкретній справі на різних стадіях іiі розгляду. Тоді як «доведення» буде складатися 3 процесу доказування та розумової й процесуальної діяльності, спрямованої на формування в судді переконання в достовірності юридичних обставин справи, на цій підставі обгрунтованості вимог сторони ${ }^{16}$.

Отже, за підходами вказаних учених, доведення $є$ ширшим поняттям, яке включає в себе доказування, де останнє охоплює збирання, витребування та надання до суду доказів, а всі інші дії, «спрямовані на забезпечення сприятливого для сторони рішення суду», варто вважати «доведенням» ${ }^{17,18}$.

Без сумніву вищезазначені підходи є науково обгрунтованими. Водночас особливістю доказування у справах про порушення митних правил $є$ те, що цей процес може відбуватися як на етапі складення

14 Приймаченко Д.П. Докази у провадженні у справах про порушення митних правил : автореф. дис. ... канд. юрид. наук. Ірпінь, 2002. С. 9-10.

15 Фурса С.Я., Цюра Т.В. Докази і доказування у цивільному процесі : науково-практичний посібник. (Серія: Процесуальні науки). Київ : Видавець Фурса С.Я., КНТ, 2005. 256 c. C. 14.

16 Фурса С.Я., Цюра Т.В. Докази і доказування у цивільному процесі : науково-практичний посібник. (Серія: Процесуальні науки). Київ: Видавець Фурса С.Я., КНТ, 2005. 256 c. C. 21

17 Фурса С.Я., Цюра Т.В. Докази і доказування у цивільному процесі : Науково-практичний посібник. (Серія : Процесуальні науки). Київ : Видавець Фурса С.Я., КНТ, 2005. 256 c. C. 14

18 Андрійцьо В.Д. Понятійний апарат процесу судового доказування цивільного судочинства (історико-правовий підхід). Вісник Вищої ради юстииії. Серія «Питання процесу та судової практики».2013. № 2 (14). C. 60-61. URL: http://www.vru.gov.ua/content/article/ visnik14_06.pdf (дата звернення: 28.02.2020). 
протоколу про порушення митних правил, так і під час здійснення подальшого провадження, а по деяких категорій справ і в суді (санкція яких передбачає конфіскацію). Тому доцільно під час розкриття обраної теми дослідити наявні напрацювання в частині доказування в судових процесах.

У науковій літературі під час дослідження структури процесу доказування вчені виділяють декілька стадій (елементів). Думки правознавців щодо кількості й наявності елементів у структурі доказування різноманітні й досить дискусійні, проте об’єднує їх те, що доказування в усіх випадках розглядається як зміна етапів, що послідовно відбуваються один за одним, - операцій, які призводять до зміни дійсності.

С.С. Бичкова, досліджуючи процес доказування в суді, виділяє три етапи: 1) збирання доказів; 2) дослідження доказів; 3) їх оцінювання. Збирання доказів, на іï думку, - це процесуальна діяльність суду та інших учасників цивільного процесу щодо залучення доказів, яка, у свою чергу, складається 3: а) подання доказів сторонами та іншими особами, які беруть участь у справі; б) витребування доказів судом; в) надання судових доручень щодо збирання доказів. Такого ж триелементного загального поділу дотримується й В.В. Комаров.

Професор Д.А. Фурсов відстоює більш широку структуру діяльності з доказування: виявлення, фіксація, збирання, зберігання, дослідження, перевірка та оцінювання доказів, надаючи кожному елементу особливої значущості. Виявлення доказів, на його думку, залежить від висування реальних версій, які визначають усі можливі варіанти ïх знаходження, а також перевірних заходів 3 приводу кожної 3 них. Фіксація доказів потрібна для їх збереження в незмінному вигляді. Вона може мати місце в протокольній формі, у письмових доказах або на електронних носіях ${ }^{19}$.

Досліджуючи структуру доказування у справах про порушення митних правил, беручи за основу вищезазначені моделі, пропонуємо виділити такі етапи: 1) безпосереднє виявлення порушення митних правил або наявність інформації про можливе вчинення порушення митних правил; 2) фіксація (документування) порушення митних правил шляхом складення протоколу або в разі наявності інформації про можливе вчинення порушення митних правил, підготовка відповідних запитів до компетентних органів (у тому числі до іноземних); 3) зберігання доказів; 4) дослідження; 5) перевірка та оцінювання доказів.

19 Стадії процесу доказування у цивільному процесі: Судова влада в Україні. URL: https://gl.lv.court.gov.ua/sud1304/knowledge_base/233009/ (дата звернення: 28.02.2020). 
Дослідження доказів - це діяльність, яка полягає в з'ясуванні їх смислу та інформаційного значення, тобто мова йде про сприйняття, вивчення інформації про факти, що містяться в передбачених законом джерелах доказів, з'ясування факторів, які впливають на достовірність доказів, порівняно $з$ окремими доказами, ліквідацію суперечностей між ними.

Оцінювання доказів - це діяльність, яка приводить до переконання про допустимість, належність, достовірність доказів і достатність їх сукупності для встановлення обставин, що мають значення для прийняття рішення.

Усі докази в справі підлягають оцінюванню. Оцінюванням доказів $€$ визначення їх відносності, допустимості, достовірності й достатності ${ }^{20}$. Посадова особа митного органу, яка здійснює провадження у справі про порушення митних правил, відповідно до митного законодавства, оцінює докази за своїм внутрішнім переконанням, яке має грунтуватися на всебічному, повному й об'єктивному дослідженні всіх обставин справи в їх сукупності, керуючись законом і правосвідомістю ${ }^{21}$.

Кодексом України про адміністративні правопорушення визначено, що обов'язок щодо збирання доказів покладається на осіб, уповноважених на складання протоколів про адміністративні правопорушення, визначених статтею 255 цього Кодексу ${ }^{22}$. Однак у наведеному переліку митних органів немає.

С.В. Додін указує, що якщо в процесі доказування мають бути встановлені факти саме реальної дійсності (інакше кажучи, об'єктивна істина), то саме вони мають бути підгрунтям винесення правозастосовного рішення. Якщо зібрана інформація не відповідає дійсності (не є об'єктивною істиною), не може бути й обгрунтованого, правомірного рішення.

Метою доказування може бути лише істина об'єктивна, а якщо вона не є об'єктивною, то вона не може іменуватися істиною загалом ${ }^{23}$. Отже, наведена позиція С.В. Додіна свідчить про вирішальне

20 Корнута Л.М. Визначення поняття доказів та доказової діяльності в дисциплінарному провадженні щодо державних службовців. Актуальні проблеми держави і права. Одеса, 2014. С. 32.

21 Митний кодекс України : Закон України від 13 березня 2012 р. № 4495-VI / Верховна Рада України. URL: https://zakon.rada.gov.ua/laws/show/4495-17 (дата звернення: 28.02.2020).

22 Кодекс України про адміністративні правопорушення: Закон України від 7 грудня 1984 р. № 8073-X / Верховна Рада України. URL: https://zakon.rada.gov.ua/laws/show/ 80731-10 (дата звернення: 28.02.2020).

23 Додин Е.В. Доказывание и доказательства в правоприменительной деятельности органов советского государственного управления. Киев ; Одесса : Вища школа, 1976. С. 78. 
значення достовірності як властивості тих чи інших доказів під час обгрунтування уповноваженою особою свого рішення про застосування дисциплінарної відповідальності щодо державних службовців. Жоден із доказів не має переважної сили перед іншими доказами ${ }^{24}$.

Додатковими стадіями доказування у справах про порушення митних правил можна також уважати збирання доказів; отримання свідчень, їх використання; направлення матеріалів справи про порушення митних правил (за окремими статтями) до суду; розгляд справи про порушення митних правил; винесення постанови та іiі перегляд у зв’язку з оскарженням.

\section{2. Шляхи удосконалення процесу доказування у справах про порушення митних правил}

Доказування у справах про порушення митних правил є складним i різновидним процесом. Кожна категорія справ про порушення митних правил має свої особливості, які насамперед пов'язані з видом митного режиму, моментом настання відповідальності, колом суб'єктів, які можуть бути притягнуті до адміністративної відповідальності за порушення митних правил, тощо. 3 урахуванням зазначеного, процес доказування також у кожній справі є унікальним.

Ще одна особливість доказування у справах про порушення митних правил характеризується великим обсягом документообігу, пов'язаних зі специфікою діяльності митних органів і полягає в різноманітті різних видів документів, які використовуються як джерела доказів ${ }^{25}$. При цьому чітко визначений порядок доказування (використання лише передбачених законом джерел відомостей, обов'язкова процедура отримання та фіксації знань уповноваженими особами, суворо визначена форма тощо), відображаючи гносеологічні та психологічні закономірності й досягнення правозастосовної практики, є оптимальним, тобто найбільш ефективним і доцільним для вирішення завдань адміністративної юрисдикційної правозастосовної діяльності. Це процесуальний порядок сприяє досягненню справжнього й достовірного знання, забезпечує

24 Корнута Л.М. Визначення поняття доказів та доказової діяльності в дисциплінарному провадженні щодо державних службовців. Актуальні проблеми держави і права. Одеса, 2014. C. 32.

25 Немирова Т.А., Гольтяпина И.Ю., Базиль В.В. Актуальные вопросы выявления административных правонарушений в сфере таможенного дела. Эпоха науки. Серия «Юридические науки». 2018. № 16. С. 41-46. DOI 10.24411/2409-3203-2018-11611. 
правильність прийнятих рішень, їх суспільне визнання та належний виховний ефект ${ }^{26,27 .}$

30 грудня 2004 р. Наказом Державної митної служби України № 936 з метою однакового застосування норм керівниками митниць, їх заступниками, а також посадовими особами митних органів, уповноваженими складати протоколи про порушення митних правил і здійснювати провадження у справах про порушення митних правил, затверджені Методичні рекомендації щодо провадження у справах про порушення митних правил ${ }^{28}$, які в подальшому, відповідно до Наказу Державної митної служби України від 18 січня 2013 р. № 15, утратили чинність ${ }^{29}$.

Розділ 4 Методичних рекомендацій щодо провадження у справах про порушення митних правил мав назву «Докази у справі про порушення митних правил». Зокрема, у цьому розділі містилися норми, якими розкривалося саме поняття «доказ», зазначався перелік даних, які мають доказове значення.

У пункті 4.1 розділу 4 Методичних рекомендацій щодо провадження у справах про порушення митних правил вказувався перелік обставин, які підлягали доказуванню під час провадження у справі про порушення митних правил, а саме: 1) подія порушення митних правил (час, місце, спосіб та інші обставини вчинення правопорушення); 2) наявність у діях правопорушника вини у формі умислу або необережності, мотив учинення порушення митних правил; 3) обставини, що пом’якшують та обтяжують відповідальність; 4) наслідки правопорушення, характер і розмір заподіяної шкоди; 5) інші обставини, що мають значення для прийняття правильного рішення у справі.

Для встановлення перерахованих обставин, з'ясування об'єктивної істини у справі потрібно зібрати, дослідити, оцінити й використати всі докази ${ }^{30}$.

26 Лузгин И.М. Расследование как процесс познания. Москва, 1968.

27 Чернявська О.М. Докази та доказування у справах про порушення митних правил: до питання вдосконалення правового забезпечення. Lex portus. 2019. № 3. C. 56. URL: http://nbuv.gov.ua/UJRN/LP_2019_3_6 (дата звернення: 28.02.2020).

28 Про затвердження Методичних рекомендацій щодо провадження у справах про порушення : Наказ Державної митної служби України від 30 грудня 2004 року № 936 (утратив чинність). Державна митна служба Украӥни. URL: https: https://ips.ligazakon.net/document/ view/MK041273 (дата звернення: 28.02.2020).

29 Про визнання такими, що втратили чинність, деяких наказів Держмитслужби України : Наказ Державної митної служби України від 18.01.2013 № 15 / Державна митна служба України. URL: https://zakon.rada.gov.ua/rada/show/en/v0015342-13\#n10 (дата звернення: 28.02.2020).

30 Про затвердження Методичних рекомендацій щодо провадження у справах про порушення : Наказ Державної митної служби України від 30 грудня 2004 р. № 936 (утратили чинність) / Державна митна служба України. URL: https: https:/ips.ligazakon.net/document/ view/MK041273 (дата звернення: 28.02.2020). 
Після визнання нечинними Методичних рекомендацій щодо провадження у справах про порушення митних правил нових не розроблено.

Ураховуючи вищезазначене, варто на законодавчому рівні розробити методичні рекомендації з розгляду справ про порушення митних правил, один із розділів яких повинен бути присвячено доказуванню. Окрім цього, у вищих навчальних закладах необхідно запровадити спеціальний курс для комплексного вивчення майбутніми митниками процесу доказування у справах про порушення митних правил, організовувати на постійній основі в межах підвищення кваліфікації працівників митниці семінари, тренінги, покликані вдосконалити практичні навики, отримати нові знання. Як варіант це можуть бути курси профайлінгу, психологічного спрямування, роботи на поліграфі тощо.

Запропоноване дасть змогу більш кваліфікаційно, якісно, повно та вчасно встановлювати істину по кожній порушеній справі, виключити випадки безпідставного притягнення суб'єктів до адміністративної відповідальності й закриття справ за відсутністю складу адміністративного проступку, закінчення термінів притягнення до відповідальності.

Ще одним із важливих кроків на шляху вдосконалення здійснення митних розслідувань, відповідно, і процесу доказування у справах про порушення митних правил є фактичне надання працівникам оперативних підрозділів територіальних митних органів, які ведуть боротьбу 3 контрабандою, повноважень здійснювати оперативно-розшукову діяльність. Важливо відмітити, що функція здійснення працівниками митного органу оперативно-розшукової діяльності на законодавчому рівні закріплена в Законі України «Про оперативно-розшукову діяльність» ${ }^{31}$, Митному кодексі України ${ }^{32}$, однак фактично довгий час мала лише декларативний характер.

Нині, відповідно до Положення про Державну митну службу України, затвердженого Постановою Кабінету Міністрів від 6 березня 2019 р. № 227, повноваженнями щодо організації та проведення відповідно до закону оперативно-розшукової діяльності, здійснення контролю за ії провадженням оперативними підрозділами Держмитслужби та іiі територіальних органів, які ведуть боротьбу з контрабандою; взаємодії в межах повноважень, визначених законом, з іншими органами,

31 Про оперативно-розшукову діяльність: Закон України від 18 лютого 1992 р. № 2135-XII / Верховна Рада України. URL: https://zakon.rada.gov.ua/laws/show/2135-12 (дата звернення: 28.02.2020).

32 Митний кодекс України : Закон України від 13 березня 2012 р. № 4495-VI / Верховна Рада України. URL: https://zakon.rada.gov.ua/laws/show/4495-17 (дата звернення: 28.02.2020). 
що провадять таку діяльність; ужиття в межах повноважень, визначених законом, заходів щодо відшкодування завданих державі збитків наділена Держана митна служба України як центральний орган ${ }^{33}$.

I хоча завданням оперативно-розшукової діяльності $\epsilon$ пошук і фіксація фактичних даних про протиправні діяння осіб, відповідальність за які передбачена Кримінальним кодексом України ${ }^{34}$, однак, ураховуючи, що деякі відкриті провадження закриваються за відсутністю складу кримінального порушення та направляються для подальшого розслідування в порядку, передбаченому законодавством про адміністративні правопорушення, фактичне наділення працівників оперативних підрозділів митниці такими повноваженнями сприяло б покращенню роботи в частині оперативного та всебічного збирання необхідної інформації.

Окрім зазначеного, негласний контроль може застосовуватися 3 метою вилучення товарів, щодо яких є підозра в незаконному переміщенні через митний кордон України.

У будь-якому разі організація та проведення негласних дій насамперед спрямовані на отримання відомостей, що входять до предмета доказування.

Одним із завдань, покладених на Державну митну службу України, $\epsilon$ участь у міжнародному співробітництві з питань протидії порушенням митних правил. У зв'язку з цим пріоритетним напрямом, спрямованим на покращення доказування у справах про порушення митних правил, $є$ нагальна необхідність налагодження взаємодії з іншими органами іноземних держав, створення єдиних інформаційних баз. У цій частині вже існує деякий прогрес, однак, на жаль, не з усіма країнами.

\section{ВИСНОВКИ}

Доказування у справах про порушення митних правил $є$ унікальним і складним процесом. За результатами наукового дослідження виокремлено структурні елементи (стадії), властиві саме процесу доказування у справах про порушення митних правил. 3'ясовано, що процес встановлення істини у справі про порушення митних правил залежить від багатьох факторів.

33 Положення про Державну митну службу України : Постанова Кабінету Міністрів України від 6 березня 2019 р. № 227 / Верховна Рада України. URL: https://zakon.rada.gov.ua/ laws/show/227-2019-\%D0\%BF/print\#n209 (дата звернення: 28.02.2020).

34 Кримінальний кодекс України : Закон України від 5 квітня 2001 р. № 2341-III / Верховна Рада України. URL: https://zakon.rada.gov.ua/laws/show/2341-14 (дата звернення: 28.02.2020). 
3 метою вдосконалення процесу доказування у справах про порушення митних правил розроблено низку пропозицій, зумовлених наявністю проблемних питань у цих правових відносинах.

По-перше, існує нагальна необхідність у перегляді чинних нормативно-правових актів, що регулюють інститут доказування у справах про порушення митних правил. У зв'язку з цим доцільно внести зміни до Митного кодексу України та Кодексу України про адміністративні правопорушення, доповнивши їх положеннями про доказування. Унесення таких змін дасть змогу більш детальніше врегулювати суспільні відносини, що складаються в процесі доказування у справах про порушення митних правил, виключити корупційні ризики, випадки зловживання правами чи повноваженнями тощо.

Окрім цього, у межах нормативного вдосконалення вважаємо за необхідне розроблення методичних рекомендацій, спрямованих на покращення роботи посадових осіб під час здійснення провадження у справах про порушення митних правил, у яких окремий розділ буде присвячений процесу доказування.

По-друге, важливим є питання кадрової політики. Зокрема, підвищення професійної підготовки посадових осіб митного органу, до повноважень яких зараховано складення протоколу, здійснення провадження у справах про порушення митних правил, а також спеціалістів, залучених до процесу доказування; фактичне розширення повноважень працівників митного органу; надання працівникам доступу до інформаційних баз даних (у тому числі міжнародних); налагодження взаємодії з іншими інституціями.

Така необхідність зумовлена притаманністю інституту доказування у справах про порушення митних правил особливостей, які можуть проявлятися залежно від стадії, категорії митної справи, суб'єкта, який виносить рішення у справі про порушення митних правил (суд, посадова особа митного органу), місця вчинення адміністративного проступку тощо. Технологічний прогрес диктує нові виклики, які зумовлюють використання сучасної техніки, обладнання.

Тому лише комплексний підхід до нормативного врегулювання, отримання відповідних навиків персоналом, забезпечення митних органів сучасними технічними засобами сприятимуть виявленню й фіксуванню порушень, запобіганню порушенням на митному кордоні, а в подальшому й усебічному встановленню істини. 


\section{АНОТАЦІЯ}

Одним із важливих етапів здійснення провадження у справах про порушення митних правил $є$ доказування. Саме від нього залежить у подальшому, буде визнано суб'єкта винним у вчиненні адміністративного правопорушення чи ні. Питання вжиття заходів щодо доказування посадовими особами митного органу врегульовано нормами національного законодавства поверхово. Ці відносини потребують удосконалення, зумовленого викликами часу, необхідністю використання нових технологій, практичних навиків і вмінь, які будуть корисні під час збирання інформації, оцінювання та прийняття рішень.

У зв'язку з цим пропонується розробити практичні рекомендації щодо кожної з основних категорій справ про порушення митних правил. Важливим $\epsilon$ перегляд обсягу компетенції посадових осіб митниці та фактичне надання їм повноважень на здійснення оперативно-розшукової діяльності.

Окремо в дослідженні акцентовано увагу на необхідності умов для проходження працівниками митного органу відповідних курсів, тренінгів, практичних завдань, покликаних підвищити їхній професійний рівень знань, отримати додаткові навички, які пришвидшать процес установлення істини у справах про порушення митних правил, удосконалять якість процесу доказування.

Налагодження взаємодії як між іншими національними органами та службами, так і міжнародними залишається актуальним питанням. Створення єдиних інформаційних баз даних, надання до них доступу всім зацікавленим службам, технічна можливість обміну інформацією повинні бути пріоритетним завданням.

\section{ЛIТЕРАТУРА}

1. Андрійцьо В.Д. Понятійний апарат процесу судового доказування цивільного судочинства (історико-правовий підхід). Вісник Вищої ради юстииії. Серія «Питання прочесу та судової практики». 2013. № 2 (14). C. 60-61. URL: http://www.vru.gov.ua/content/article/visnik14_06.pdf (дата звернення: 28.02.2020).

2. Білак Н.І., Прокопенко В.В. Переміщення товарів, які містять об'єкти права інтелектуальної власності, через митний кордон України : монографія. Дніпро: Університет митної справи та фінансів, 2019. С. 148-149.

3. Грабовська О.О. Теоретико-правові проблеми доказування у цивільному процесі України : автореф. дис. ... докт. юрид. наук. Київ, 2019. C. 7. URL: http://scc.univ.kiev.ua/upload/iblock/e43/aref_Grabovska\%20 O.\%20A..pdf (дата звернення: 28.02.2020). 
4. Додин Е.В. Доказывание и доказательства в правоприменительной деятельности органов советского государственного управления. Киев ; Одесса : Вища школа, 1976. С. 78.

5. Корнута Л.М. Визначення поняття доказів та доказової діяльності в дисциплінарному провадженні щодо державних службовців. Актуальні проблеми держави і права. Одеса, 2014. С. 32.

6. Кодекс України про адміністративні правопорушення: Закон України від 7 грудня 1984 р. № 8073-X / Верховна Рада України. URL: https://zakon.rada.gov.ua/laws/show/80731-10 (дата звернення: 28.02.2020).

7. Кодекс адміністративного судочинства України : Закон України від 6 липня 2005 р. № 2747-IV / Верховна Рада України. URL: https://zakon. rada.gov.ua/laws/show/2747-15/print (дата звернення: 28.02.2020).

8. Кримінальний кодекс України : Закон України від 5 квітня 2001 p. № 2341-III / Верховна Рада України. URL: https://zakon.rada.gov.ua/laws/ show/2341-14 (дата звернення: 28.02.2020).

9. Кримінальний процесуальний кодекс України : Закон України від 13 квітня 2012 р. № 4651-VI / Верховна Рада України. URL: https://zakon. rada.gov.ua/laws/show/4651-17/card6\#Public (дата звернення: 28.02.2020).

10. Лузгин И.М. Расследование как процесс познания. Москва, 1967.

11. Митний кодекс України: Закон України від 13 березня 2012 р. № 4495-VI / Верховна Рада України. URL: https://zakon.rada.gov.ua/laws/ show/4495-17 (дата звернення: 28.02.2020).

12. Немирова Т.А., Гольтяпина И.Ю., Базиль В.В. Актуальные вопросы выявления административных правонарушений в сфере таможенного дела. Эпоха науки. Серия «Юридические науки». 2018. № 16. С. 41-46. DOI 10.24411/2409-3203-2018-11611.

13. Положення про Державну митну службу України : Постанова Кабінету Міністрів України від 6 березня 2019 р. № 227 / Верховна Рада України. URL: https://zakon.rada.gov.ua/laws/show/227-2019-\%D0\%BF/ print\#n209 (дата звернення: 28.02.2020).

14. Приймаченко Д.П. Докази у провадженні у справах про порушення митних правил : автореф. дис. ... канд. юрид. наук. Ірпінь, 2002. С. 9-10.

15. Про визнання такими, що втратили чинність, деяких наказів Держмитслужби України : Наказ Державної митної служби України від 18.01.2013 № 15 / Державна митна служба України. URL: https://zakon. rada.gov.ua/rada/show/en/v0015342-13\#n10 (дата звернення: 28.02.2020).

16. Про затвердження Методичних рекомендацій щодо провадження у справах про порушення : Наказ Державної митної служби України від 30 грудня 2004 року № 936 (утратив чинність) / Державна митна служба України. URL: https: https://ips.ligazakon.net/document/view/ MK041273 (дата звернення: 28.02.2020). 
17. Прокопенко В.В., Калакайло P.І. Процесуальні дії у справах про порушення митних правил : монографія. Чернівці : Техгодрук, 2015. С. 31.

18. Про оперативно-розшукову діяльність : Закон України від 18 лютого 1992 p. № 2135-XII / Верховна Рада України. URL: https://zakon.rada.gov. ua/laws/show/2135-12 (дата звернення: 28.02.2020).

19. Про утворення Державної податкової служби України та Державної митної служби України : Постанова Кабінету Міністрів від 18 грудня 2018 p. № 1200 / Верховна Рада України. URL: https://www.kmu.gov.ua/npas/ pro-utvorennya-derzhavnoyi-podatkovoyi-sluzhbi-ukrayini-ta-derzhavnoyimitnoyi-sluzhbi-ukrayini (дата звернення: 28.02.2020).

20. Солопова І.В. Специфіка доказування у митних провадженнях. Актуальні проблеми політики. 2015. Вип. 56. С. 280.

21. Стадії процесу доказування у цивільному процесі: Судова влада в Україні. URL: https://gl.lv.court.gov.ua/sud1304/knowledge_base/233009/ (дата звернення: 28.02.2020).

22. Фурса С.Я., Цюра Т.В. Докази і доказування у цивільному процесі : науково-практичний посібник. (Серія: Процесуальні науки). Київ : Видавець Фурса С.Я., КНТ, 2005. 256 с. С. 14.

23. Цивільний процесуальний кодекс України : Закон України від 18 березня 2004 p. № 1618-IV / Верховна Рада України. URL: https://zakon. rada.gov.ua/laws/show/1618-15/print (дата звернення: 28.02.2020).

24. Чернявська О.М. Докази та доказування у справах про порушення митних правил: до питання вдосконалення правового забезпечення. Lex portus. 2019. № 3. C. 50-58. URL: http://nbuv.gov.ua/UJRN/LP_2019_3_6.

\section{Information about authors:}

Bilak N. I.,

Candidate of Law,

Deputy Chief of the Southern Interregional Directorate for the Execution of Criminal Punishments and Probation of the Ministry of Justice on the Observance of the Rights of Convicted Persons and Persons Imprisoned 9, Lustdorf Road, Odessa, Ukraine

Chernyavskaya O. M.,

Postgraduate Student of the National University "Odessa Law Academy", Deputy Head of Customs Post "Odessa International Airport" State Customs Service of Ukraine 21-A, Ivan and Yuriy Lip Street Odessa, Ukraine DOI https://doi.org/10.30525/978-9934-588-43-3/1.22 